\title{
EFEKTIVITAS PENGGUNAAN MEDIA BOOKLET TERHADAP PENGETAHUAN GIZI SEIMBANG PADA IBU BALITA GIZI KURANG DI KELURAHAN SEMANGGI KECAMATAN PASAR KLIWON KOTA SURAKARTA
}

\author{
Yessie Finandita Pratiwi ${ }^{1}$, Dyah Intan Puspitasari ${ }^{2}$ \\ ${ }^{1,2}$ Program Studi Ilmu Gizi Fakultas Ilmu Kesehatan Universitas Muhammadiyah \\ Surakarta. Jl. A. Yani, Pabelan, Kartasura, Surakarta. \\ Email: ${ }^{1}$ yessie.finandita@yahoo.com, ${ }^{2}$ dyah.puspitasari@ums.ac.id
}

\begin{abstract}
ABSTRAK
Tujuan penelitian ini adalah untuk mengetahui efektivitas penggunaan media booklet terhadap pengetahuan gizi seimbang pada ibu balita gizi kurang. Jenis penelitian yang digunakan adalah quasi eksperimen dengan rancangan pretest posttest with control group. Penelitian dilakukan terhadap 60 ibu balita, yang dibagi menjadi $30 \mathrm{ibu}$ balita pada kelompok eskperimen dan $30 \mathrm{ibu}$ balita pada kelompok kontrol. Pengetahuan dinilai dari hasil pretest dan posttest. Kelompok eksperimen diberikan metode ceramah dengan menggunakan media booklet. Kelompok kontrol diberikan metode ceramah tanpa menggunakan media booklet. Hasil uji wilcoxon signed rank test bahwa pengetahuan gizi awal dan akhir pada kelompok kontrol terdapat perbedaan yang signifikan $(\mathrm{p}=0,000)$, pada kelompok eksperimen pengetahuan gizi awal dan akhir memiliki perbedaan yang signifikan $(\mathrm{p}=0,000)$. Hasil uji independent t-test tidak terdapat peningkatan yang bermakna pada selisih nilai pengetahuan gizi seimbang pada kelompok kontrol dengan kelompok eksperimen $(\mathrm{p}=0,114)$. Secara statistik, tidak terdapat efektivitas dalam penggunaan media booklet terhadap pengetahuan gizi seimbang pada ibu balita gizi kurang tetapi terdapat peningkatan nilai rata-rata 4,8 pada kelompok eksperimen.
\end{abstract}

Kata kunci: Ibu balita gizi kurang, media booklet, pendidikan gizi, pengetahuan gizi seimbang

\begin{abstract}
The purpose of the study was to determine the effectiveness of the booklet media to the knowledge of balanced nutrition in underweight children under five. The type of research used was quasi-experiment with pretest-posttest and control group design. The study was conducted on 60 mothers of under five children, were divided into 30 mothers in the experimental group and 30 mothers in the control group. Knowledge was valued from pretest and posttest results. The experimental group was given lecture method using booklet media, while the control group was given lecture method without booklet media. The Wilcoxon signed rank test displayed that the initial and final nutrition knowledge in the control group had significant
\end{abstract}


differences $(\mathrm{p}=0.000)$. In the experimental group of early and final nutritional knowledge had a significant difference $(\mathrm{p}=0.000)$. Independent t-test showed that there was no significant improvement in the difference of balanced nutrition knowledge value in the control group with the experimental group $(\mathrm{p}=0.114)$. Statistically, the use of booklet media did not effective to improve the knowledge of mother but there was an improvement of the average value of 4.8 in experiment group.

Keywords : Mothers of under-five, booklet media, nutrition education, knowledge of balanced nutrition

\section{PENDAHULUAN}

Asupan makan maupan pola makan balita menentukan kesuksesan dalam tumbuh dan berkembang (Kodyat, 2014). Asupan makan yang tidak seimbang yaitu asupan makan yang defisit menyebabkan balita mengalami periode kritis seperti gizi kurang. Kekurangan gizi pada balita bahkan terjadinya gizi buruk dapat menyebabkan kematian (Ochtaviani dan Ani, 2012). Hasil Riskesdas (2013) terjadi peningkatan angka prevalensi gizi kurang di Indonesia yaitu 13,0\% menjadi $13,9 \%$. Kondisi sosial ekonomi seperti pekerjaan ibu, pendidikan ibu, pengetahuan dan pola asuh ibu, jumlah anak serta kondisi ekonomi dapat mempengaruhi terjadinya gizi kurang pada balita (Putri dkk., 2015).

Pengetahuan ibu dalam pengaturan konsumsi makan dengan pola makan seimbang sangat diperlukan untuk menjadikan balita memiliki status gizi baik. Perilaku yang positif dapat dibentuk dari pengetahuan yang baik, sehingga cara yang tepat untuk meningkatkan pengetahuan adalah dengan menggunakan media sebagai pendidikan kesehatan (Ma'munah, 2015). Pengetahuan gizi ibu meliputi mampu membuat makanan yang memiliki komposisi beraneka ragam atau bervariasi untuk dikonsumsi balita sehingga kebutuhan zat gizi balita dapat tercukupi (Veriyal, 2010). Hasil penelitian Setyawati dkk. (2015) menunjukkan bahwa pendidikan gizi menggunakan booklet dapat meningkatkan pengetahuan ibu mengenai gizi pada anak. Hal ini didukung oleh Zulaekah (2012) menunjukkan bahwa pemberian pendidikan gizi dengan metode booklet dapat memperbaiki tingkat pengetahuan gizi.

Pada provinsi Jawa Tengah mengalami peningkatan dari $14,0 \%$ menjadi $19,0 \%$ prevalensi balita yang mengalami gizi kurang pada tahun 2010 hingga 2013. Kota Surakarta tahun 2016 terdapat $6,7 \%$ prevalensi balita yang mengalami gizi kurang, dan Puskesmas Sangkrah merupakan puskesmas dengan prevalensi gizi kurang tertinggi yaitu 3,2\% dan penyebaran gizi kurang paling besar yaitu di kelurahan Semanggi sebesar 3\% sehingga masuk dalam keadaan rawan gizi (DKK Surakarta, 2016).

Survei pendahuluan di Kelurahan Semanggi terdapat $65 \%$ ibu memiliki pengetahuan gizi kurang, terdapat $10 \%$ ibu memiliki pengetahuan gizi sedang, dan $25 \%$ ibu memiliki pengetahuan gizi baik. Oleh karena itu, penelitian ini bertujuan untuk mengetahui efektivitas penggunaan media booklet terhadap pengetahuan gizi seimbang pada ibu balita gizi kurang di Kelurahan Semanggi Kecamatan Pasar Kliwon Kota Surakarta.

\section{METODE PENELITIAN}

Jenis penelitian ini adalah quasi eksperiment dengan rancangan pretest 
posttest with control group. Kelompok eskperimen diberikan metode ceramah dengan media booklet dan kelompok kontrol hanya diberikan metode ceramah. Lokasi penelitian adalah di Kelurahan Semanggi. Penelitian dilaksanakan pada 19 Oktober hingga 13 November 2016.

\section{Responden}

Populasi adalah ibu yang memilki balita gizi kurang yaitu 73 ibu balita sedangkan yang memenuhi kriteria inklusi dan eksklusi adalah 60 ibu balita. Kriteria insklusi meliputi ibu balita bertempat tinggal di Kelurahan Semanggi, memiliki balita gizi kurang, berumur 19 hingga 45 tahun, tidak bekerja, ibu mengasuh sendiri balitanya, dapat berkomunikasi dengan baik dan bersedia menjadi responden penelitian. Adapun kriteria eksklusi adalah ibu balita tidak datang saat penelitian dan ibu balita pindah rumah tanpa konfirmasi yang jelas.

Dari 60 ibu balita dibagi menjadi dua kelompok yaitu kelompok kontrol dan kelompok eksperimen. Masing-masing kelompok terdapat $30 \mathrm{ibu}$ balita dengan proporsi yang sama. Sampel diambil sesuai dengan pendidikan terakhir ibu, sehingga kedua kelompok memiliki kesamaan.

Ibu balita pada masing-masing kelompok dilakukan dua kali pertemuan dan dua kali pendidikan gizi. Setiap pertemuan diberikan pendidikan gizi selama 30 menit. Pertemuan pertama diberikan soal pretest sebelum dilakukan pendidikan gizi. Pertemuan kedua setelah dilakukan pendidikan gizi diberikan soal posttest. Pertemuan pertama dan pertemuan kedua diberikan jeda waktu dua hari. Hal ini dilakukan agar meminimalisir penyebaran media booklet yang diberikan pada kelompok eksperimen.

\section{Data pengetahuan gizi seimbang}

Data penelitian meliputi data pengetahuan gizi seimbang. Instrumen yang digunakan adalah kuesioner pengetahuan gizi seimbang. Data pengetahuan gizi seimbang ibu balita diperoleh dari kuesioner pengetahuan gizi seimbang yang diadopsi dari Asransyah (2016) dengan jumlah soal sebanyak 20 soal yang telah diuji reliabilitasnya dengan nilai Alpha 0,836. Jika jawaban benar maka diberikan nilai 1 dan jika salah diberikan nilai 0 . Hasil skor pengetahuan dikelompokkan menjadi tiga kategori yaitu pengetahuan baik jika skor pengetahuan $>80 \%$, pengetahuan sedang jika skor pengetahuan 60-80\%, dan pengetahuan kurang jika skor pengetahuan $<60 \%$ (Khomsan, 2000).

\section{Analisis data}

Data karakteristik responden adalah pengetahuan gizi seimbang dianalisis secara univariat atau deskriptif. Analisis bivariat dilakukan dengan menggunakan software SPSS 20,0 dengan menguji normalitas data menggunakan uji Kolmogorov-Smirnov kemudian dilanjutkan dengan uji Wilcoxon Signed Rank Test karena data berdistribusi tidak normal. Untuk mengetahui perbedan nilai rata-rata dua sampel yang berhubungan digunakan uji independent t-test karena data berdistribusi normal.

\section{HASIL DAN PEMBAHASAN}

\section{Karakteristik Sampel}

Tabel 1. Distribusi Frekuensi Sampel Berdasarkan Umur

\begin{tabular}{ccc}
\hline Umur Ibu (Tahun) & \multicolumn{2}{c}{ Kelompok } \\
\cline { 2 - 3 } & Kontrol & Eksperimen \\
\hline $17-25$ & $5(16,7 \%)$ & $5(16,7 \%)$ \\
$26-45$ & $24(80 \%)$ & $24(80 \%)$ \\
$46-55$ & $1(3,3 \%)$ & $1(3,3 \%)$ \\
\hline
\end{tabular}


Tabel 1 menunjukkan bahwa usia sampel pada penelitian berada pada kisaran umur 26-45 tahun yaitu sebanyak $80 \%$. Pada kelompok kontrol dan kelompok eksperimen memiliki penyebaran umur yang sama. Rata-rata umur ibu balita pada kelompok kontrol yaitu 31,7 $\pm 6,39$ tahun dan kelompok eksperimen adalah 32,5 $\pm 5,55$ tahun. Pada dua kelompok perlakuan ibu balita tertua berusia 46 tahun dan ibu balita termuda berusia 20 tahun.

Tabel 2. Distribusi Frekuensi Sampel

Berdasarkan Pendidikan

\begin{tabular}{|c|c|c|}
\hline \multirow{2}{*}{$\begin{array}{c}\text { Pendidikan } \\
\text { Ibu }\end{array}$} & \multicolumn{2}{|c|}{ Kelompok } \\
\hline & Kontrol & Eksperimen \\
\hline SD & $7(23,3 \%)$ & $7(23,3 \%)$ \\
\hline SMP & $11(36,7 \%)$ & $10(33,3 \%)$ \\
\hline SMA & $12(40 \%)$ & $13(43,3 \%)$ \\
\hline
\end{tabular}

frekuensi pendidikan ibu tertinggi adalah lulus SMA pada kelompok kontrol maupun kelompok eksperimen. Pada kelompok kontrol terdapat $40 \%$ ibu yang lulus SMA, dan pada kelompok eksperimen terdapat $43,3 \%$ ibu yang lulus SMA. Notoatmodjo (2007) menyatakan bahwa pendidikan merupakan faktor yang mempengaruhi pengetahuan. Semakin tinggi pendidikan maka semakin baik tingkat pengetahuan sebab pendidikan sama halnya dengan proses belajar serta proses pengajaran. Oleh sebab itu, manusia memiliki keterampilan yang dibutuhkan dalam hidup bermasyarakat. Menurut Berihu (2013), ibu yang hanya dapat menulis dan membaca memiliki pengetahuan yang lebih rendah dibandingkan dengan ibu yang memiliki pendidikan sekunder. Oleh sebab itu, terdapat perbedaan pengetahuan dengan tingkat kependidikan ibu.

Tabel 3. Distribusi Karakteristik Keluarga Berdasarkan Ekonomi

\begin{tabular}{ccc}
\hline \multirow{2}{*}{ Penghasilan } & \multicolumn{2}{c}{ Kelompok } \\
\cline { 2 - 3 } & Kontrol & Eksperimen \\
\hline Kurang dari UMR & $20(66,7 \%)$ & $24(80 \%)$ \\
Lebih dari UMR & $10(33,3 \%)$ & $6(20 \%)$ \\
\hline
\end{tabular}

Tabel 3 menunjukkan bahwa pada kelompok kontrol frekuensi paling tinggi adalah keluarga dengan penghasilan kurang dari UMR sebanyak 66,7\%. Sama halnya dengan kelompok eksperimen, frekuensi paling tinggi sebanyak $80 \%$ adalah keluarga dengan penghasilan kurang dari UMR yaitu 1.418.000.

\section{Karakteristik Pengetahuan Ibu tentang Gizi Seimbang}

Tabel 4. Distribusi Tingkat Pengetahuan Gizi Seimbang pada Ibu Balita Gizi Kurang Kelompok Kontrol

\begin{tabular}{ll}
\hline Variabel & Kontrol \\
\hline Pengetahuan Gizi Pre Test & \\
Kurang & $20(66,7 \%)$ \\
Sedang & $10(33,3 \%)$ \\
Baik & $0(0 \%)$ \\
Pengetahuan Gizi Post Test & \\
Kurang & $0(0 \%)$ \\
Sedang & $15(50 \%)$ \\
Baik & $15(50 \%)$ \\
\hline \multicolumn{2}{c}{ Tabel 4 menunjukkan bahwa nilai }
\end{tabular}
pengetahuan gizi awal atau pretest yang masuk dalam kategori pengetahuan gizi kurang sebesar $66,7 \%$. Sampel dengan kategori pengetahuan gizi sedang mengalami peningkatan. Dari hasil pretest sebesar $33,3 \%$ mengalami peningkatan menjadi $50 \%$ pada hasil posttest. Hasil pretest tidak terdapat sampel yang masuk dalam kategori pengetahuan gizi baik, sedangkan pada hasil posttest terdapat $50 \%$ sampel masuk dalam kategori pengetahuan gizi baik. Hal ini sesuai dengan Supariasa (2012) terjadinya peningkatan skor pengetahuan dibuktikan dengan keunggulan metode ceramah yaitu efisiensi penggunaan waktu, sesuai untuk kelompok sasaran yang besar, dan pengaturan yang mudah. Selain itu pendidikan kesehatan bertujuan untuk mengubah pengetahuan maupun pemahaman, sehingga metode ceramah merupakan salah satu metode pendidikan yang dapat mengubah pengetahuan maupun pemahaman. 
Tabel 5. Distribusi Nilai Pengetahuan tentang Gizi Seimbang pada Ibu Balita Gizi Kurang pada Kelompok Kontrol

\begin{tabular}{lc}
\hline Variabel & Kontrol \\
\hline Pre Test & \\
Minimal & 45,00 \\
Maksimal & 75,00 \\
Rata-rata & 53,66 \\
SD & 7,97 \\
Post Test & \\
Minimal & 60,00 \\
Maksimal & 95,00 \\
Rata-rata & 81,16 \\
SD & 9,16 \\
\hline p-value & $0,000^{\mathrm{a}}$ \\
\hline
\end{tabular}

\section{a. Wilcoxon Signed Rank Test}

Tabel 5 menunjukkan bahwa terjadi peningkatan pengetahuan sampel dengan nilai rata-rata pada pretest dan posttest dari 53,66 $\pm 7,97$ menjadi $81,16 \pm 9,16$ dan berdasarkan uji wilcoxon terdapat perbedaan yang signifikan $(\mathrm{p}=0,000)$ pada pengetahuan gizi awal dan akhir pada kelompok kontrol. Hal ini sesuai dengan penelitian Kusumaningtyas (2011) bahwa terdapat perbedaan yang signifikan $(\mathrm{p}<0,000)$ pada hasil pretest dan posttest terhadap pengetahuan ibu mengenai pemberian makanan tambahan yang baik untuk balita menggunakan metode ceramah. Hal ini dibuktikan dengan penelitian Hartono dkk. (2015) yang menunjukkan bahwa terjadi peningkatan skor pengetahuan tentang pemilihan jajanan sehat pada pretest dan posttest.

Tabel 6. Distribusi Tingkat Pengetahuan Gizi Seimbang pada Ibu Balita Gizi Kurang Kelompok Eksperimen

\begin{tabular}{ll}
\hline Variabel & Eksperimen \\
\hline $\begin{array}{l}\text { Pengetahuan Gizi Pre Test } \\
\text { Kurang }\end{array}$ & \\
Sedang & $16(53,3 \%)$ \\
Baik & $13(43,3 \%)$ \\
& $1(3,3 \%)$ \\
Pengetahuan Gizi Post Test & \\
Kurang & \\
Sedang & $0(0 \%)$ \\
Baik & $2(6,7 \%)$ \\
& $28(93,3 \%)$ \\
\hline
\end{tabular}

Tabel 6 menunjukkan bahwa nilai pengetahuan gizi awal atau pretest termasuk dalam kategori pengetahuan gizi kurang sebesar 53,3\%. Terjadi peningkatan pada kategori pengetahuan gizi baik menjadi $93,3 \%$ yang sebelum diberikan pendidikan kesehatan hanya $3,3 \%$.

Tabel 7. Distribusi Nilai Pengetahuan tentang Gizi Seimbang pada Ibu Balita Gizi Kurang pada Kelompok Eksperimen

\begin{tabular}{ll}
\hline Variabel & Eksperimen \\
\hline Pre Test & \\
Minimal & 45,00 \\
Maksimal & 85,00 \\
Rata-rata & 57,66 \\
SD & 8,27 \\
Post Test & \\
Minimal & 60,00 \\
Maksimal & 100,00 \\
Rata-rata & 90,00 \\
SD & 7,19 \\
\hline p-value & $0,000 \mathrm{a}$ \\
\hline \multicolumn{1}{c}{ Tabel }
\end{tabular}

Tabel 7 menunjukkan bahwa kelompok eksperimen terdapat peningkatan terhadap pengetahuan ibu dengan nilai rata-rata dari $57,66 \pm 8,27$ menjadi 90,00 $\pm 7,19$. Hasil uji Wilcoxon Signed Rank Test menunjukkan bahwa pengetahuan gizi awal dan akhir pada kelompok eksperimen terdapat perbedaan yang sangat signifikan $(\mathrm{p}=0,000)$.

Hal ini sejalan dengan penelitian Rathore (2014) dan Fernandes (2013) bahwa terdapat peningkatan pengetahuan pada ibu setelah diberikan pendidikan kesehatan dengan media booklet, sehingga informasi pada booklet sangat efektif untuk peningkatan pengetahuan pada ibu. Hal ini dibuktikan dengan penelitian Sumaryati (2003) bahwa terdapat perbedaan signifikan pada pengetahuan siswi tentang anemia sebelum dan sesudah diberikan intervensi dengan media booklet. Booklet akan memberikan kesan kepada pembaca jika disajikan dengan gambar yang menarik sehingga booklet tidak formal dan kaku (Nurfathiyah, 2014). Kelebihan booklet seperti dapat 
disimpan dalam waktu yang relatif lama, dapat dipelajari secara mandiri, dapat membantu media lain, selain itu booklet juga memiliki kelemahan yaitu pembaca dituntut untuk memiliki kemampuan membaca (Suiraoka, 2012).

Proses membaca menghasilkan pengetahuan. Proses yang dapat masuk dalam otak manusia yaitu $10 \%$ proses dari hal-hal yang dibaca, $20 \%$ proses dari halhal yang dilihat, $30 \%$ proses dari hal-hal yang didengar dan dilihat serta $50 \%$ dari yang dilihat dan didengar, sehingga seseorang mudah untuk memahami pengetahuan yang didapat pada saat diberikan pendidikan kesehatan dengan menggunakan media (Budioro, 2007).

Berdasarkan Tabel 5 dan Tabel 7 masing-masing kelompok memiliki nilai pretest pengetahuan gizi yang tergolong kurang. Hal ini dapat diartikan bahwa kedua kelompok memiliki tingkatan yang sama. Nilai rata-rata hasil posttest kelompok eksperimen lebih tinggi daripada kelompok kontrol sehingga tingkat pengetahuan ibu balita yang diberikan metode ceramah menggunakan media booklet lebih tinggi dibandingkan diberikan metode ceramah saja. Hal ini dibuktikan dengan penelitian Apriani (2013) yang menyatakan bahwa terdapat peningkatan pengetahuan yang lebih besar pada kelompok wanita usia subur yang mendapatkan pendidikan kesehatan dengan media booklet daripada wanita usia subur yang mendapatkan pendidikan kesehatan dengan metode ceramah tanpa media booklet.

Tabel 8. Distribusi Selisih Nilai

Pengetahuan tentang Gizi Seimbang pada Ibu Balita Gizi Kurang pada Kelompok Kontrol dan Kelompok Eksperimen

\begin{tabular}{llll}
\hline \multirow{2}{*}{ Variabel } & \multicolumn{2}{c}{ Kelompok } & \multirow{2}{*}{ p-value } \\
\cline { 2 - 3 } & Kontrol & Eksperimen & \\
\hline Peningkatan & & & \\
Minimal & $-10,00$ & 0,00 & $0,114^{\mathrm{a}}$ \\
Maksimal & 45,00 & 50,00 & \\
Rata-rata & 27,5 & 32,3 & \\
SD & 12,08 & 11,19 & \\
& & & \\
\hline
\end{tabular}

\section{b. Independent t-test}

Berdasarkan Tabel 8 rata-rata peningkatan nilai pengetahuan gizi kelompok kontrol adalah 27,5 $\pm 12,08$. Sedangkan pada kelompok eksperimen peningkatan nilai pengetahuan gizi adalah $32,3 \pm 11,19$. Selisih rata-rata nilai pengetahuan antara kelompok kontrol dan kelompok eksperimen adalah 4,8, sehingga kelompok eksperimen memiliki peningkatan nilai pengetahuan lebih tinggi dibandingkan dengan kelompok kontrol.

Selisih nilai pengetahuan pretest dan posttest kelompok kontrol terjadi penurunan yaitu $-10,00$ ini terjadi karena banyak faktor seperti adanya balita yang menangis, ibu yang membawa balita sehingga konsentrasi ibu terganggu. Oleh sebab itu, pengerjaan kuesioner posttest tidak maksimal. Pada kelompok eksperimen terjadi peningkatan skor hingga 50,00.

Hasil uji Independent t-test membuktikan bahwa tidak terdapat peningkatan yang bermakna $(p=0,114)$ pada nilai pengetahuan gizi tentang gizi seimbang pada kelompok kontrol maupun eksperimen. Dari hasil penelitian, kedua kelompok sama-sama mengalami peningkatan pengetahuan .

Dibuktikan dengan penelitian Astuti (2015) bahwa pada kelompok kontrol (ceramah tanpa media komik) dan kelompok eksperimen (ceramah dengan media komik) tidak memiliki perbedaan peningkatan yang bermakna $(\mathrm{p}=0,567$; $\mathrm{p}>0,05)$ pada nilai pengetahuan gizi tentang anemia. Sejalan dengan penelitian Cahyono (2015) bahwa tidak terdapat perbedaan peningkatan yang signifikan $(\mathrm{p}=0,848 ; \mathrm{p}>0,05)$ pada kelompok kontrol (ceramah) dan kelompok eksperimen (video animasi) terhadap pengetahuan siswi tentang anemia.

Hal ini bisa terjadi karena pada setiap kelompok perlakuan memiliki pendidikan dan umur yang sama rata. Dibuktikan berdasarkan hasil penelitian 
bahwa $80 \%$ ibu berusia $26-45$ tahun pada kedua kelompok perlakuan. Usia 26-45 tahun tergolong usia dewasa awal dan dewasa akhir atau menuju pada lanjut usia (Depkes, 2009). Hal ini sejalan dengan pernyataan Gummi (1922-1992) yang dikutip dari buku (Hidayati dkk., 2008) bahwa pada usia 0-30 tahun merupakan tahapan pertumbuhan dan perkembangan yang berkelanjutan. Kematangan penuh dari fisik dan intelektual terdapat pada usia 0-30 tahun. Oleh sebab itu, dapat disimpulkan bahwa pada rentang usia 2645 merupakan masa yang mudah untuk menerima informasi.

Selain umur, pendidikan juga berpengaruh dalam menentukan hasil penelitian. Pada kelompok kontrol terdapat $40 \%$ ibu berpendidikan SMA dan $43,3 \%$ ibu berpendidikan SMA pada kelompok eksperimen. Menurut Nursalam dan Ferry (2008) bahwa proses belajar yang dialami seseorang dapat mengubah aspek pengetahuan (kognitif), sikap (afektif), dan keterampilan (psikomotor) dalam hal perilaku. Fungsi pendidikan baik formal maupun non formal adalah untuk memperbanyak ilmu pengetahuan. Sesuai dengan pernyataan Permatasari (2008) bahwa seseorang akan menginterpretasi informasi yang didapat dengan baik apabila memiliki tingkat pendidikan yang tinggi, sehingga semakin tinggi pendidikan semakin mudah menerima informasi tentang gizi. Oleh sebab itu, ibu yang berpendidikan SMA lebih mudah menerima informasi dibandingkan dengan ibu yang berpendidikan SD dan SMP. Hal ini beriringan dengan penelitian Banu (2012) bahwa pengetahuan mengenai pemberian ASI meningkat signifikan atau memiliki pengetahuan yang baik pada orang tua yang memiliki pendidikan tinggi (SMP hingga SMA). Selain itu, menurut SA dkk. (2009) latar belakang pendidikan mempengaruhi hasil dari pengetahuan, sikap, dan perilaku. Ibu yang memiliki pendidikan rendah memiliki nilai pengetahuan, sikap, dan perilaku lebih rendah daripada ibu yang memiliki pengetahuan tinggi (SMA).

Oleh karena itu, tingginya pendidikan ibu dan usia ibu yang produktif menjadikan berbagai metode pendidikan gizi dapat diaplikasikan. Peningkatan pengetahuan dari kategori sedang menjadi kategori baik dari setiap kelompok membuktikan bahwa dengan media ceramah saja mampu meningkatkan pengetahuan ibu. Secara statistik media booklet tidak efektif untuk meningkatkan pengetahuan tetapi memiliki kecenderungan untuk meningkatkan pengetahuan karena memiliki rata-rata 4,8 lebih tinggi dibandinglan dengan tanpa media booklet.

\section{KESIMPULAN}

Kesimpulan dari penelitian ini adalah pengetahuan gizi seimbang ibu balita pada kelompok kontrol sebelum diberikan penyuluhan sebesar $66,7 \%$ tergolong kurang, pengetahuan gizi seimbang ibu balita setelah diberikan penyuluhan pada kelompok kontrol sebesar 50\% tergolong baik dan 50\% tergolong sedang. Pada kelompok eksperimen, pengetahuan gizi seimbang ibu balita sebelum diberikan penyuluhan sebesar 53,3\% tergolong kurang, pengetahuan gizi seimbang ibu balita setelah diberikan penyuluhan pada kelompok eksperimen 93,3\% tergolong baik. Pada kelompok kontrol, terdapat perbedaan yang signifikan pada pengetahuan gizi awal dan akhir $(\mathrm{p}=0,000)$. Pada kelompok eksperimen, terdapat perbedaan yang signifikan pada pengetahuan gizi awal dan akhir $(p=0,000)$. Tidak terdapat peningkatan yang bermakna pada selisih nilai pengetahuan gizi seimbang pada kelompok kontrol dengan kelompok eksperimen $(\mathrm{p}=0,114)$. 


\section{DAFTAR PUSTAKA}

Apriani, Arista., 2013, Perbedaan Pengaruh Pendidikan Kesehatan dengan Metode Ceramah Dibandingkan Booklet terhadap Pengetahuan dan Sikap tentang Deteksi Dini Kanker Payudara pada Wanita Usia Subur di Kabupaten Magetan Jawa Timur, Tesis, Program Pasca Sarjana Universitas Sebelas Maret, Surakarta.

Asransyah., 2016, Hubungan Lama Pendidikan dan Pengetahuan Ibu Tentang Gizi Seimbang Dengan Perilaku Pemberian Makan Anak Balita di Puskesmas Gilingan Surakarta, Skripsi, Program Studi Ilmu Gizi Fakultas Ilmu Kesehatan Universitas Muhammadiyah Surakarta, Surakarta.

Astuti, Ratna Arditya Tri., 2015, Efektivitas Penggunaan Media Komik terhadap Peningkatan Pengetahuan Gizi dan Daya Terima pada Remaja Putri, Skripsi, Program Ilmu Gizi Fakultas Ilmu Kesehatan Universitas Muhammadiyah Surakarta, Surakarta.

Banu, Bilkis, Khurshida Khanom., 2012, Effects of Education Level of Father and Mother on Perceptions of Breastfeeding, Dhaka, J Enam Med Col Vol 2 No 2.

Berihu, Amanuel, Gerez Giher Buruh Abera, Hailemariam Berhe, Kalayou Kidanu., 2013, Mother's Knowlegde on Nutritional Requirement of Infant and Young Child Feeding in Mekelle, Ethiopia, Cross Sectional Study, USA, Global Journals Inc.

Budioro, B., 2007, Pengantar Pendidikan (Penyuluhan) Kesehatan Masyarakat edisi 2. Universitas Diponegoro, Semarang.

Cahyono, Surastomo Budi., 2015, Peningkatan Pengetahuan Siswa tentang Anemia Setelah Mendapatkan Pendidikan Gizi dengan Media Video Animasi, Skripsi, Program Ilmu Gizi Fakultas Ilmu Kesehatan Universitas Muhammadiyah Surakarta, Surakarta.

Departemen Kesehatan Republik Indonesia., 2009, Profil Kesehatan 2008. http://www.depkes.go.id, diakses 20 November 2016.

Fernandes, Philomena, Shiney Paul, Savitha B., 2013, Effectiveness of an Information Booklet on Knowledge Among Staff Nurses Regarding Prevention and Management of Perineal Tear During Normal Delivery, Nitte University Journal of Health Science, Mangalore.

Hartono, Nur Pratiwi, Catur Saptaning Wilujeng, Sri Andarini., 2015, Pendidikan Gizi tentang Pengetahuan Pemilihan Jajanan Sehat antara Metode Ceramah dengan Metode Komik, Indonesian Jurnal of Human Nutrition, Malang.

Hidayati, Wiji, Sri Purnami., 2008, Psikologi Perkembangan, Teras, Yogyakarta. 
Khomsan, Ali., 2000, Teknik Pengukuran Pengetahuan Gizi (diktat), Fakultas Ekologi Manusia Institut Pertanian Bogor, Bogor.

Kodyat, Benny A., 2014, Pedoman Gizi Seimbang 2014. Permenkes RI No. 41 Tahun 2014, Yogyakarta.

Kusumaningtyas, Dyah Ambarini., 2011, Pengaruh Penyuluhan Gizi terhadap Tingkat Pengetahuan Ibu Mengenai Pemberian Makanan Tambahan yang Biak untuk Balita, Universitas Sebelas Maret, Surakarta.

Ma'munah, Malikatul., 2015, Pengaruh Pendidikan Kesehatan dengan Booklet terhadap Pengetahuan Ibu Laktasi di Wilayah Kerja Puskesmas Ciputat Timur, Program Studi Ilmu Keperawatan Fakultas Kedokteran dan Ilmu Kesehatan Universitas Islam Negeri Syarif Hidayatullah, Jakarta.

Notoatmodjo, Soekidjo., 2007, Kesehatan Masyarakat Ilmu dan Seni, Rineka Cipta, Jakarta.

Nurfathiyah, Pera., 2014, Pengaruh Penggunaan Ilustrasi dan Bahasa pada Media Buklet terhadap Peningkatan Pengetahuan Petani di Kabupaten Muara Jambi, Jurnal Penelitian Universitas Jambi Seri Sains, Jambi.

Nursalam, Ferry Efendi., 2008, Pendidikan dalam Keperawatan, Salemba Medika, Jakarta.

Octaviani, Irma Aryati, Ani Margawati., 2012, Hubungan Pengetahuan dan Perilaku Ibu Buruh Pabrik tentang Kadarzi (Keluarg Sadar Gizi) dengan Status Gizi Anak Balita (Studi di Kelurahan Pagersari Ungaran), Journal of Nutrition Collage, Program Studi Ilmu Gizi Fakultas Kedoketeran Universitas Diponegoro, Semarang.

Permatasari, Nathalia Yuli Indah., 2008, Hubungan Antara Tingkat Pendidikan dan Pengetahuan Ibu dari Anak Taman Kanak-kanak terhadap Pemilihan Multivitamin di Kecamatan Laweyan Kota Surakarta, Skripsi, Fakultas Farmasi Universitas Muhammadiyah Surakarta, Surakarta.

Putri, Rona Firmana, Delmi Sulastri, Yuniar Lestari., 2015, Faktor-faktor yang Berhubungan dengan Status Gizi Anak Balita di Wilayah Kerja Puskesmas Nanggalo Padang, Jurnal Kesehatan Andalas, Universitas Andalas Padang, Padang.

Rathore, Chetan Kumar, Arpan Pandya, Ravindra H N., 2014, Effectiveness of Information Booklet on Knowledge Regarding Home Menegement of Selected Common Illness in Children, IOSR Journal of Nursing and Health Science (IOSR-JNHS), e-ISSN: 2320-1959.p-ISSN: 2320-1940 Volume 3, Issue 5 Ver. I (Sep-Oct 2014), PP 80-84. 
Riset Kesehatan Dasar., 2013, Badan Penelitian dan Pengembangan Kesehatan Kementrian Kesehatan RI.

SA, Yin, Li N, Yan Z Y, Pan L, Lai J Q, Zhao X F., 2009, Effect of Nutritional Education on Improvement of Nutritional Knowledge of Infant's Mothers in Rural Area in China, National Institute for Nutrition and Food Safety, Chinese Center for Disease Control and Prevention, China.

Setyawati, Vilda Ana Veria, Bambang Agus Herlambang., 2015, Model Edukasi Gizi Berbasis E-booklet untuk Meningkatkan Pengetahuan Gizi Balita, Jurnal Informatika UPGRIS, Semarang.

Suiraoka, I Putu, I Dewa Nyoman Supariasa., 2012, Media Pendidikan Kesehatan. Graha Ilmu, Yogyakarta.

Sumaryati, Ninuk., 2003, Pengaruh Intervensi Booklet Info Anemia Gizi dalam Pencegahan dan Penanggulangan Anemia Gizi terhadap Pengetahuan dan Sikap pada Siswi Sekolah Menengah Umum Kabupaten Demak, Tesis, Magister Ilmu Kesehatan Masyarakat Universitas Diponegoro, Semarang.

Supariasa, I Dewa Nyoman., 2012, Pendidikan dan Konsultasi Gizi, EGC, Jakarta.

Veriyal, Nura., 2010, Analisis Pola Asuh Gizi Ibu terhadap Balita Kurang Energi Protein (KEP) yang Mendapat PMT-P di Puskesmas Pagedangan Kabupaten Tangerang Tahun 2010, Program Studi Kesehatan Masyarakat Fakultas Kedokteran dan Ilmu Kesehatan Universitas Islam Negeri Syarif Hidayatullah Jakarta, Jakarta.

Zulaekah, Siti., 2012, Efektivitas Pendidikan Gizi dengan Media Booklet terhadap Pengetahuan Gizi Anak SD, Jurnal Kesehatan Masyarakat Universitas Negeri Semarang, Semarang. 
JURNAL KESEHATAN, ISSN 1979-7621, Vol. 10, No. 1. Juni 2017 